\title{
Spastic Paraplegia 4
}

National Cancer Institute

\section{Source}

National Cancer Institute. Spastic Paraplegia 4. NCI Thesaurus. Code C129981.

An autosomal dominant condition caused by mutation(s) in the SPAST gene, encoding spastin. It is characterized by progressive lower extremity spasticity and weakness. 